$\mathbb{T}$ periodica polytechnica

\author{
Social and Management Sciences \\ $18 / 2(2010) 91+102$ \\ doi: 10.3311/pp.so.2010-2.04 \\ web: http://www.pp.bme.hu/so \\ (c) Periodica Polytechnica 2010
}

RESEARCH ARTICLE

\section{Spreading of project and virtual teams in traditional organizational cultures}

\author{
Rita Répáczki / Márta Juhász
}

Received 2010-07-14

\begin{abstract}
In our article we would like to give an overview of the recent literature about special present work arrangements emphasizing the differences between 'traditional' work and '(virtual) project team' work. 'Traditional work' means that the employee has an invariable package of tasks that he/she is responsible for. In 'project teams' members have common complex goals and there are a lot of parts of assignments that one is responsible for in the team. 'Project' means that there is a specific exercise that must be carried out in defined time and budget. The nature of work is dynamically changing and there is a new view of work in project groups. There are different antecedences and emphasises than in 'traditional work'. There is a lot of information, and information acquisition is not a problem, but one has to be very clever to structure the abounding information he/she gets. Due to technical development, it is possible to work at home and people do not need to go out to work every day. Working together with others has also become special: you may not know personally the persons you work together with, you may have only virtual contact with them. The goals and the conditions of project team work are really special and it is important to know because more and more project groups are appearing. There are project groups appearing in Hungary also. According to the "Collectively for Workplaces of the Future" Foundation's ("Közösen a Jövó Munkahelyeiért" Alapítvány) competition in 2009 we began a research related to project works in Hungarian organizations. We tried to analyze project work as an atypical type of work and we tried to also analyze how it can be appropriate to make possibilities of labour market better and ensure flexible opportunities for organizations and individuals. We analyzed such Hungarian organizations, which have one or more project teams and we tried to reveal work psychological aspects of this type of work.
\end{abstract}

\section{Rita Répáczki}

Márta Juhász

Department of Ergonomics and Psychology, BME, 1117 Budapest, Magyar tudósok körútja 2. building Q., Hungary

\section{Introduction}

Recently the structure, content, and process of work have changed. Work is now: more cognitively complex, more teambased and collaborative, more dependent on social skills, more dependent on technological competences, more time pressured, more mobile and less dependent on geography.

In today's organizations work is very different due to competitive pressures and technological breakthroughs. Organizations today are more agile, more focused on identifying value from the customer perspective, more tuned to dynamic competitive requirements and strategy, less hierarchical in structure and decision authority, less likely to provide lifelong careers and job security and continually reorganizing to maintain or gain competitive advantage [10] [16]).

Besides the dozens of changing work and organizational patterns, there are two key drivers (Heerwagen et al., 2006 [13]).

There is an increasing pressure on organizations to be more competitive, agile, and customer focused: to be a "lean enterprise". This lean enterprise model was introduced in 1970s by Toyota. The key principles of the Lean Enterprise (or Lean Thinking as it is often called) are:

- defining value from the customer's perspective,

- identifying internal activities and processes that add value for the customer and identifying linkages between them (the "value chain"),

- eliminating non-value added activities (or "waste") across the organization,

- reducing waste and inefficiencies in support (e.g., overhead) functions.

The lean enterprise principles enable many organizations to respond more rapidly to the effects of the market by reducing cycle time, developing mass customization processes and supporting continual change and innovation.

The other key driver is virtual communication equipment breakthrough that has separated work from time and space. Communication and information technology, especially mobile technologies and the Internet made the market more active and 
flexible. Due to Internet, e-mails, mobile telephone, shared documents, instant messaging, blogs, forums, videoconference, management softwares and Wikipedia we can get information very easily and can communicate very quickly.

\section{Actual specialities of labour market}

\subsection{Dissolution of the unity of work in time and space}

Employees can continue their work without any interruption due to mobile telecommunication. Work is not connected closely to workplace, since virtual offices and GroupWise systems create the possibilities of working together even in geographically dispersed locations. While working on the same project, employees can be located in different cities or in different countries using not only telephone but also the Internet, e-mail and different groupware systems. Virtual work is becoming as common as face-to-face work. Virtual teams are groups of individuals who work together from different locations, perform interdependent tasks, share responsibilities for the outcomes, and rely on technology support for much of their communications [5].

It is no more important to connect work to workplace. In project work the most important is to carry out the given exercises independent from workplace and game time. It is also possible to make people work together without so much as working face to face. Due to virtual equipment it is possible to be in communication with the others via virtual platform. That is why work is not dependent on place and time only on people who carry it out.

\subsection{Organizational changes}

In the dynamically changing world of work quick reactions and proactivity are necessary. More and more companies are realizing that their organizational structures are not capable of reacting to the fast changes of the world and employees' attitude. A large, so called "mammoth-organization" has slow processes and a lot of decision levels. An over-hierarchical company cannot be quick enough, so it should get flatter and more decentralized. Borders should disappear and the role of the leader will also change. To survive, these organizations need to apply such methodologies that make them flexible. A solution can be presented by implementing project teams. This is such a work style that can ensure more dynamism and quicker responses. Due to this work-style it is possible to harmonize changing specialities of work (such as time or place), human resource and equipment background. In project work these components of work can be formed to reach the mean aim. Near implementing project teams it is also necessary for organizations to take care of their employees, even if there are a lot of motivated and committed workers. These workers are expected to work better, but they also need to be supported, encouraged, motivated, acknowledged and rewarded.

Construction of present organizations is changing and there is a special polarization appearing in them. This tendency shows that companies are growing in size, but in addition to the large units there are smaller ones as well. Larger units usually do the traditional constant company tasks that are necessary to keep the organization alive. These are constant exercises and needed every day. But exercises related to the production or the facilities of the organization can be variable depending on the demand of the market.

\subsection{What is project work?}

Project work is a kind of atypical work, a flexible type that can adjust to the present volume of tasks. Project team work makes the organizations possible to form their labour substance to the demands. Project works have special aims. That is why in project teams members need to have special abilities and competencies in order to be able to carry out the special tasks they get. They have to feel themselves the owner of these tasks and it is their common responsibility to carry out all the exercises in time. This is a kind of contractor attitude: they are hired for carrying out the tasks, they feel themselves in a strong way responsible for it, and want to carry it out perfectly. They want to be independent from the company and take part in more and more different projects to become a professional worker. They want to be workers and also leaders of themselves. This tendency is growing, and people need to become aware of their carriers. They need to be able to choose suitable conditions and make decisions in connection with their opportunities. They need to be aware of their aspirations and take the responsibility for their carriers and lives. To be able to manage it, they need the contribution of the organization as well. Project teams the parts of the organizations and there are different ways to integrate the project teams in the organizations.

\subsection{Ways of implementing project teams in the organiza- tions}

For the sake of the cooperation between the two kinds of work (traditional and project) it is necessary to find a good way to implement project teams in the organizations.

\section{- Clear project management}

It is typical in such organizations where projects are usual and the main businesses of the organization are based on projects (e. g.: building, developing, contracting companies). Main advantage of this type of organizing is the clear and welldefined responsibility and working according to competencies. Disadvantage of it is the inflexible framework and it is also difficult to deeply implement the temporary employed workers in the organization.

\section{- Project management as a unit}

In traditional organizations it is typical to run projects temporary. To carry out these projects the leadership assigns employees from the company. This organizing is very practical because the members of the project team are also the members of the organization. Disadvantage of this organization is 
the missing responsibility for commands. It is also a problem that the project team leader has not got responsibility for the project.

\section{- Matrix project management}

This type can be run in two cases. This structure is very practical, if the organizational structure is linear but the projects are regular in the organization. It is also practical in the case if the whole organization works in a matrix structure. Advantage of it is the flexible applicability of the members of the project team and the obvious professional responsibility of the team leader. But there are also disadvantages: difficulty in the delimination of scope of activities and conflicts that can get more frequent.

\subsection{Specialities of project work}

Projects are multi-laned frames. In point of the form of work these structures are dual organizations. Because of organizational environment, project organizations change their functioning and after carrying out the task, the organization returns to the original functioning. It is necessary because there are really complex and creative exercises in projects and there are a lot of parts of the task. These creative exercises can interfere the original function of the organization, so it is very important to separate from the project. But project can not be completely separated because there are a lot of points where the project team must connect to the organization to get the needed means. Due to this duality, organizations can flexibly adapt to turbulent changes of labour market, but there are difficulties too. Employees taking part in the project have two leaders during the project period. They get directions from both leaders and these directions can oppose each other. These situations can be very difficult for the employee who wants to perform well in the functional scope of activities and in the project as well. During the project period there are two dimensions of work in the organization but after carrying out the project the organization returns to the original formation. Project is a very special type of work with advantages and disadvantages:

- More point of views: Tasks of projects are usually complex and interdisciplinar. Projects can run effectively if there are different qualified persons in it who try to solve problems through different ways. This complexity makes project team special and effective.

- Multi-lateral coordination: There is no hierarchy in real project teams. Autonomy and democracy are common and cooperation is possible and expected. There are horizontal relationships in project teams and democratic leadership is practical.

- Cooperation: Project teams have special members from and outside of the company who may have never worked together before. Intensive and concentrated work in project teams makes people get close to each other. They get acquainted with each other, they realize the importance of each others' work and they can get more effective in team work.

- Structure: Project is a complex task and there are different parts in it. There are specialists in the project team who work on specified part of the exercise according to their qualification. Project teams work as an independent organization and members get their remuneration by their performance.

- Objectivity: Project teams must be composed according to the project aims. The most important thing is to reach the aim and carry out the assumed tasks. Project team members can be estimated according to their performance and in project work they can get independent from the organization.

- Adaptability: Project organization can adapt dynamically to the economic environment, it can be reactive and proactive too. There can be more project teams in one time in the organization and they work independently from each other.

Near the advantages there are also disadvantages related to project organizations.

- Conflicts: There are peer relationships in project teams everybody must listen to each others' opinion. Before decisions they have to harmonize their opinions. In absence of it there can be a lot of conflicts in the project teams. Conflicts can also appear between the project team and the organization because responsibility for tasks is not always clear and there are a lot of resources that must be used together and there can be a conflict generated if there are not enough resources.

- Responsibility: There is common responsibility in project teams but it can turn into social loafing if the members of the team do not also feel their own responsibility in it.

- Double responsibility: There are a lot of questions related to the persons who take part in the project team. These persons have two leaders: which one is more important? How should they grade the tasks? Who can do duty for him? Project organizations are dual organizations. If project team appears in the organization the structure of the original organization capsizes and there are new problems coming up. Where is the place of the project team in the organization? Who is the leader of project team members? Who can manage the functional tasks of the project team members?

- Effectiveness: Because of projects the human resource base of the organization must be divided up. So there will be more tasks but will not be more human resource capacity. It can strip the activity of the organization and can result in decrease of effectiveness.

- Power: Project teams are flat organizations and team members have freedom and autonomy. Sometimes they do not really know their responsibility and competencies. That is why sometimes it can happen that some team members try to catch the power and tries to increase their impact. This can also cause decrease of effectiveness. 
Tab. 1. Advantages and disadvantages of project management types

\begin{tabular}{|c|c|c|}
\hline Type & Advantage & Disadvantage \\
\hline Clear project management & $\begin{array}{l}\text { Clear and obvious responsibility } \\
\text { Competency }\end{array}$ & $\begin{array}{l}\text { Inflexible organizational structure } \\
\text { High general charges } \\
\text { Implementing the temporary employed work- } \\
\text { ers in the organization }\end{array}$ \\
\hline Project management as a unit & $\begin{array}{l}\text { It is easy to implement the project team in the } \\
\text { organization } \\
\text { It is possible to handle human resources flex- } \\
\text { ible }\end{array}$ & $\begin{array}{l}\text { Missing of the responsibility for commands } \\
\text { The project team leader has not got respon- } \\
\text { sibility for the project }\end{array}$ \\
\hline Matrix project management & $\begin{array}{l}\text { It is possible to handle human resources flex- } \\
\text { ible } \\
\text { Professional responsibility of project team } \\
\text { leader }\end{array}$ & $\begin{array}{l}\text { Difficulty in the delimination of scope of activ- } \\
\text { ities } \\
\text { More frequent conflicts }\end{array}$ \\
\hline
\end{tabular}

- Lobbying: Projects need to get enough money to be successful. A lot of equipment is necessary to it: physical means, capital, specialists, etc. If there are more projects in the organization there can be a real competition among them and they can be adversary of each other.

Traditional and project work are running next to each other. There are a lot of differences between the two types of work but they must be in harmony because both of them are necessary in a successful organization. In Tab. 2 we collected the main differences between these two kinds of work.

\subsection{Accelerating rate of innovation and transfer of skills}

In a changing world, it is important to be very flexible and be able and willing to change and adapt. Lifelong learning is a buzzword today as skills need to be improved, new things need to be learnt, new knowledge and new information need to be acquired. Work activities are getting more and more difficult and complex [29]. The necessity of permanently learning new things implies difficulties for the employees and the company too. Tasks will change so quickly that it will be difficult to train people for specific tasks. It is better to train meta-skills and teach people to be able to: a) learn fast, b) select relevant information, c) ask structured questions, d) analyze the situation, e) think in a practical way, and f) adapt quickly to the situation.

Sending people to different courses and trainings is not enough and would be pointless. Developing trust and identifying groups within the organization and making sure that each group feels valued and respected is much more important. But trainings are necessary for the introduction of something new, even if it seems to be easy to carry out. Learning a skill and applying it in a work environment is not the same and there are some clues needed to ensure that members of training get capable to apply the learnt skills [9]:

- Task application knowledge: In order to be effective, workers need to know special work situations and problems and they also need to know the special equipment that can help with solving the problems. In addition, it is also necessary to be able to use these tools on their own. So workers need global knowledge to know the special problems, they need to be able to match the special problems with the special tools and they need to be able to use these special tools, softwares and equipment.

- Action styles: Goal orientation and purposefulness are also important. A high degree of them can facilitate the transfer of skills to the real situations because workers with a high degree of goal orientation and purposefulness think in terms of real situations from the beginning of the training. They are effective in transferring the new knowledge to real situations and use it practically.

- Job decision latitude: It is a part of control within work concept. People with high decision latitude can decide how the work should be done, they can decide about plans, tasks, goals, time management. Such people are usually selfefficient and creative. They are good at using the acquired new skills. They can acquire information, can understand it, and after understanding they can complete and use it practically.

\subsection{Increased complexity of work}

Changes of technology based work make work intellectually more demanding. Earlier it was difficult to get information about the accomplishment of the activities, tasks. Nowadays, it is changing; it is possible to acquire a lot of information through various channels. Because the rate of change in work is increasing, we need new knowledge and a lot of information. Global changes and developing trends are making work even more complex. It is necessary to learn how to structure the information and be able to develop together with the changing job. To be able to manage it, we need special tools and capable people. The software world and the variety of technological equipment help us in structuring knowledge but it is also important to manage it successfully.

White collar workers are expected to be more functional and cognitively fluid and able to work in different kinds of tasks and 
Tab. 2. Main differences between traditional and project work

\begin{tabular}{lll}
\hline & Traditional work & Project work \\
\hline Hierarchy & yes & no \\
Speed of reactions & slow & fast \\
Organizational culture & one type & mixture of organizational cultures \\
Unity of time and place & unity is present & unity is missing \\
Knowledge & basic knowledge, standard tasks & new knowledge, lifelong learning \\
Equipment & less mobile technology & mobile technology explosion \\
Management perspective & rules and orders & less rules and orders, but rather to be committed to orga- \\
& & nizational goals and mission \\
Most important personal skills & accuracy, regularity & complex intellectual, social, emotional skills \\
Interaction & mainly personal (less virtual) & through different channels (personal and virtual ways) \\
Decisions & responsibility of the leader & all members have their own decision fields \\
Leadership style & "Mr. Leader X” & „Mr. Leader Y.” \\
\hline
\end{tabular}

situations. Successful employees need not only to be intelligent and professional but also to be capable of effective team work. Numerous knowledge-based tasks require analytical and judgment skills to carry out work, because work is more novel, extemporaneous, and context-based, with few rules and structured ways of working. Although the need for good cognitive skills is especially prominent in professional, technical, and managerial jobs, even administrative tasks require more independent decision making and operational decision making. Working in cross-functional and cross-boundary teams requires "kaleidoscope thinking", the ability of seeing alternative angles and perspectives and of creating new patterns of thinking that facilitate innovation. Workers also need to be able to synthesize various ideas in order to underlie innovation. It is well known that cognitive ability affects performance [6]. There is a positive relationship between cognitive ability and business success. Those with a high degree of cognitive ability are better able to deal with complex tasks and they are more successful.

Related to cognitive ability we must mention planning skills. Planning ability means that the person is able to manage time, can understand variability and complexity of tasks and can structure them. Planning skills are as important as cognitive ability and being able to plan successfully is more important for those with poorer cognitive ability. Both cognitive ability and planning skill can be developed for better performance [8].

\section{Impacts of the organizational changes}

Organizations are always under reorganizing, they have only short stabile periods. The highly hierarchysed organization structure impedes relatively quick answers to the continuously changing labour market demands. Instead of hierarchy organizations need cross-unit organizational teams with fewer layers and more decentralized decision making. Different departments of the organization need to cooperate. Organizations need more cooperation to function effectively, so boundaries between departments are getting broken down, while the information, tasks and knowledge need to be shared. Project team-based work results in making rapid decision, reducing inefficiencies, and con- tinually improving work processes.

\subsection{Work attitude in project-team}

The quality of problem solution and task performance depends on the employees' work attitude. A committed, motivated and achievement driven worker will work harder and will invest more energy to carry out the actual task in order to fulfil it at a high level. All the team members are experts of a special field and they feel themselves competent in their professional fields. The team-members' attitude to the task is usually positive and due to this optimism, they manage time pressure and unforeseeable aspects of the work efficiently, which is very typical of project-team work. The flexible aspects of the work can raise commitment and motivation of team-members. They work with high autonomy and they are allowed to work in a free-style mode. Project team members are open to develop and shape themselves continuously depending on the specialities of the actual exercise. Openness and flexibility are the basic aspects of the project team members' competitiveness. Traditional organizations will also have to interiorize this approach in order to be able to stay alive. Reasons for existence of organizations now and later are flexibility and adaptation [7], [28]. As members of a project team, members must have multifunctional skills. They are expected to be functionally and cognitively fluid and able to work across different kinds of tasks and situations. They are also expected to have wider knowledge, and to also be effective in others' tasks. They need prominent cognitive skills in professional, technical, and managerial jobs, as well as administrative tasks require more independent decision making and operational decision making. Learning, developing new skills and getting fresh information is not a privilege anymore. It is essential for all workers to be up-to-date in their jobs and in the events of the business world. Project workers need the ability to see alternatives to create new patterns of solution and innovation. They need to have different ideas and be able to synthesize the essences of them. Members of project teams are experts who are responsible for a special field of the project goals but they also have to be flexible enough to be able to care of com- 
mon goals and be able to substitute each other if it is necessary. This substitution can only be periodical and the team leader has to find the special experts to the given tasks as soon as possible.

Members of the project teams feel that project is a part of every day tasks. It is a routine for them and do not feel it special. Functional workers find projects something special because they feel that projects have priority in the organization and if there is a project it is the most important aim to carry it out successfully in time. Leaders of the organization also support projects and they try to help employees to be able to perform the indicators of the project and also to be able to handle functional tasks. It is very important for the success of the project to have open and motivated members with good qualities and practical soft competencies. Being performance and achievement oriented is also necessary to be successful in the project. Projects give possibility to an alternative way of carrier and self-realization. Project works make the members possible to get such information and knowledge that are not possible to reach if somebody is not the member of a project team. Project gives inspiration and excursion from routine. It also motivates members to perform as well as possible. Accomplishments of projects make work of the employees of the organization easier and make customers more satisfied. Work attitude differs between project team members and functional workers. Members of project teams have a more upto-date work attitude, a so called Y-approach and they think that work is appropriate for self-realization [18].

\subsection{Tasks and responsibility in project teams}

Unlike traditional organizations where everybody is responsible only for his/her own tasks, in a project team beyond the own tasks all the team-members feel responsible to obtain the goal and they have a global approach to work. Due to this global approach they are open to get feedback about their work, to improve abilities, to study new skills and to support each other. Owing to the technical development and the extended work complexity a modern approach to work is forming in which the employees need a complex basis of equipment. In many cases working in project teams implies working and communicating virtually especially if the team members' work is geographically dispersed. Type of tasks is different in project teams and responsibility is usually higher than in traditional work environment. Responsibility is affected specially if there are not any leaders in the team from the beginning of the work.

Project works seem to be more structured, complex and programable. Roles in projects are well-defined and members of the teams have huge autonomy in work. Members have to be motivated to handle double responsibility because they have to stand in the gap in functional tasks as well as in project. Sometimes they have to work at home and at the weekend, they have less free time, so it can be hard to manage all of the exercises. Project members have to have better time management because they have more deadlines and more tasks than employees in functional work [18].

\subsection{Self-managed teams}

It is typical in self-managed teams that there are not any appointed leaders in the team. It is the part of the team-process to find the person in the group who is the best to be the leader. It is also typical in these teams to be run by shared leadership. Related to shared leadership these teams work in a democratic way.

All the team members are responsible for themselves as much as for the whole team. They have enough time to deal with tasks and persons, so members of self-managed teams are usually more satisfied. They are not only more satisfied but also more effective and coordination and cooperation are also better in these teams [30]. In project teams members have more autonomy than in functional work. Every team member is responsible for his/her decisions and he/she can manage processes according to his/her conception.

In project teams working with shared leadership and autonomy a special cognitive process will appear that we call transitive memory. It is a common cognitive platform in the team that contains information being necessary in teamwork. In order to generate this common platform, team members must communicate a lot and they have to ensure that teammates can get the important information. It is important for team members to know the same information to accomplish effective team work. To share information team members have to talk a lot about work and they can also use shared folders, documents, on-line platforms. In project teams members have more intensive teamfeeling than people in functional work. They have mutual goals, they cotton to each other, and they feel that they have the same fate. Implicit coordination is also more typical in project teams than in functional work. These employees have an exact map about each others' abilities, competencies and they also have a common language. They communicate more consciously and effectively [18].

\subsection{Shared mental model}

The shared mental model is used to explain team functioning. Shared mental models help to explain how teams are able to cope with difficult and changing task conditions, because the ability to adapt is an important skill in high-performance teams [3]. The mental models are organized knowledge structures that allow individuals to interact with their environment. Specifically, mental models allow people to predict and explain the behaviour of the world around them, to recognize and remember relationships among components of the environment, and to construct expectations for what is likely to occur next. Furthermore, mental models allow people to draw inferences, make predictions, understand phenomena, decide which actions to take, which alternative to choose for making decisions. Teams must adapt quickly to changing task demands based on shared or common mental models. In order to adapt effectively, team members need to be able to predict what their teammates are going to do and what they are going to need in order to do it. Hence, 
the function of shared mental models is to allow team members to draw on their own well-structured knowledge as a basis for selecting actions that are consistent and coordinated with their teammates.

Under such conditions that allow team members freely communicate with one another - to form the strategy - shared mental models will not be very important, because the team can discuss its next moves, plans and does not need to rely on pre-existing knowledge. However, under conditions in which communication is difficult - caused by high workload, time pressure, or some other environmental feature - teams have no possibility to form a strategy. In this case, shared mental models become crucial to team functioning because they allow members to predict the information and resource requirements of their teammates. Hence, team members have a common basis of their understanding of the task demands and their team's response. This is what helps teams to adapt quickly to dynamic environments successfully.

There is probably not a single mental model that must be shared among team members. Klimoski and Mohammed [19] argued that probably multiple mental models would be coexisting among team members at a given time. These include models of task/technology, of response routines, of team work. There are several mental models, first of all about the complex tasks.

- Team members must understand the technology or equipment by means of which they are interacting.

- Team members must have shared job or task models, which describe and organize knowledge about how the task is accomplished in terms of procedures, task strategies, likely contingencies or problems, and environmental conditions.

- Team members must have shared conceptions of how the team interacts. These models describe the roles and responsibilities of team members, interaction patterns, information flow and communication channels, role interdependencies, and information sources.

- The final model that team members must share is the team member model that contains information about teammates, their knowledge, skills, attitudes, preferences, strengths, weaknesses, tendencies, and so forth.

This knowledge is crucial for team effectiveness because it allows the team members to adjust their behaviour in accordance with that they expect their teammates to do. The more knowledge team members have about one another, the more efficient and automatic this process can be [24].

This creates a shared mental model among team-members that can affect coordination and integration in the team. Project teams usually work under a high financial responsibility, so the common goods and this shared mental model are necessary to manage an expensive project successfully.

Team-members are motivated to finish the project successfully because it can be a positive reference in their future work-life and their carrier. Working in a project-team an in-

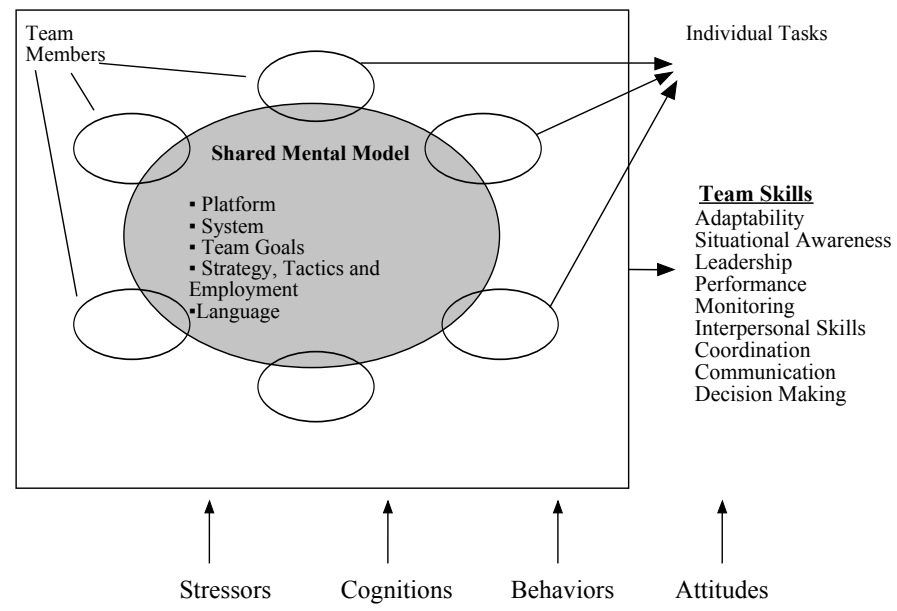

Fig. 1. The influence of shared mental model on the team-process [17]

creased amount of communication and information exchanged between the members aided by ICT (information and communication technology)-equipments (e.g. groupware programmes) can be experienced. The use of these supportive technologies by project-team members results in a relatively quick formation of common knowledge and understanding about the process and the goals, and about each others' knowledge, abilities and necessity.

Interaction in project teams must be active and team members must communicate a lot for common knowledge. It is important that the members of the project team know the same facts about goals and tasks. The way by it can be sured must be found. If it is a face-to-face team they have to organize meetings and collate regularly. In virtual project teams team members can use telephone, video-conference, instant messaging, etc. for generating shared knowledge and shared mental model.

\subsection{Individual differences in the team}

It is never easy to work together. Team members need social and interactive competencies in order to be able to adapt to the changing tasks and environment. As mentioned above project workers are "ideally" opener and more flexible than employees working in traditional organisations and they may adapt to changes and be able to tolerate ambiguous situations as well as time pressure better. Having social skills, team members are better equipped to deal with problems, to listen and understand different perspectives, and to resolve issues in mutually beneficial ways. For professional team functioning, sharing information is really important, and necessary to develop the trust in the team. When workers trust each other, they are more committed to attain the same goals and more likely to help each other in case of difficulties, and more willing to share and develop new ideas together.

In team work both task and person orientations are needed to reach the goal especially under high task loads. To maintain both of them at the same time, project teams need to be composed of real experts in their own fields and they need to be able to cooperate with each others so they need to possess good inter- 
personal, social skills. These social skills must be above average and can ensure special empathy and social sensibility.

Cooperation in a project team is very typical because the boundaries of duties are flexible. There are specialists in project teams who are responsible for their own tasks. Besides they consider themselves, mates who have the same goals and to reach these goals they are also willing to help each other. They try to get know their colleagues' fields of work and in any case be able to substitute each other. By working and solving problems together the team-members are getting mentally closer to each other. Their own parts of knowledge reach each other and they will likely think the same. Hence, the cooperation and communication help forming the common ground, common knowledge in the team and every team member has a shared mental interpretation about the situation, about the task, about each other's skills, needs, etc.

Self efficacy means believing in ourselves and in our abilities, and it is very important for effective work. Self efficacy is important in every scope of activities, also in project works and in functional work. Burn-out is not typical at project team members. Project tasks can be overhead, but these tasks are interesting and they are able to keep from burn out. Personality profiles of project team members are different from profiles of functional workers. Project workers are opener, more extravert and conscientious. Their emotional stability is high and they are more even-tempered. These features are very important in project work. In such types of exercises, openness and creativity are very important to find the best solutions of the problems. Project tasks are usually team tasks, so extraversion and social approach are also necessary. There are a lot of ad hoc tasks in project work, so emotional stability is also important. Level of autonomy is usually high in project tasks, that is why high conscientiousness is needed for effective work. Members of projects are usually performance and authority motivated. It means that they assume responsibility, want to affect the processes and they want to perform very well. Trust is also higher among project team members, because they work intensively together, they get to know each other, so trust among them can be high. Due to trust, team members can strongly bind to the team and commitment to project will also get stronger. High commitment of team members is favourable for the individual and the organization too [18].

\subsection{Leadership style}

With the nature of work changing the relationship between leaders and employees is also transforming. Employees are loyal to their tasks, but loyalty and commitment to the organization is getting reduced. Nowadays the most important for employees is their own learning and career and the acquisition of knowledge and development of technical skills. Knowledge and skills are transportable, so they are not lost when they undertake a new job. A new management approach is needed by modern organizations. Workers do not need so many rules and orders as it was thought before. Employees need to have more decision authority and latitude and they need to know the goals and the mission of the organization. Instead of being commanders, managers should become social supporters and coaches. As the time and space specialities of work are changing, characteristics of the leadership should also change. Formality of leadership should be reduced [11]. Leader position in a project team is temporary and comes into existence because of a special competency related to the actual task. This position can be held till the end of the project, so the leader should have an "entrepreneur approach" and should be able to apply skills of transformational leadership style. In absence of these, leaders will not be able to practice leadership effectively [31],[2]. These project teams need McGregor's "Mr. Leader Y", who believes that people seek independence, self-development and creativity in their work; they look beyond immediate circumstances and can adapt to new ones. They are fundamentally moral and responsible, and will strive for the good of the organisation if they are treated as such. On the other hand, traditional organizations usually led by "Mr. Leader X" who thinks that people cannot be trusted, employees are lazy, irrational and unreliable, and need to be controlled. It is necessary to motivate them by money and threat them by punishment. Without control they will pursue their own goals, which will be contrary to those of the organisation [23]. Many earlier results show that Power Distance Index and Uncertainty Avoidance Index (GLOBE, Global Leadership and Organizational Behavior Effectiveness, [14] are usually high in collectivistic cultures. But on the other hand this Power Distance Index may be less among project team leaders and project team members, so sudden, unexpected and ambiguous information can be handled very quickly by them.

The role of the leader is changing in project teams. The "new leader" should be an expert of a special field who can also coordinate processes of the team members. With a good leader teams can become even more effective and can be more successful in teamwork. A good leader is a good communicator who is able to ensure the fluency of information. In addition, intellectual, emotional and social intelligence is also very important for present leaders.

Project team leaders seem more understressed than functional leaders. It is typical that project team members also have to work under stress and workload is really high in project teams because of time pressure and number of tasks. Task orientation is expected in these teams so leaders have less time to take attention and care of persons and relationships. That is why team members can feel that their leaders spend less time with them than it would be necessary. Project team members often feel that their leaders do not know enough about them. It is necessary for project team members to get such tasks what they can develop their abilities and carrier possibilities by. Functional leaders have more time to manage cases of the employees so these leaders seem to be better in human resource management. Functional workers feel that their leaders rely on their profes- 
sional competencies. These leaders can better stand for their teams' cases. Reason for it can be that they are leaders for a long time in the organization and they have more powerful prestige than project team leaders. Project team leaders become leaders for a short period of time and this time is not enough to be really effective. It is also typical that project team leaders function as coaches, their supportive and directive behaviour activities are also high. It is needed for them and for the success of the project, because the period of a project is a short and very intensive period with a lot of tasks. That is why project team leaders can feel that they have to coordinate everything and everybody in the project team [18].

\section{Attributes of virtual teams}

There is significant difference working alone or working in a team. People usually like working in a team, because it is good to belong to a group and not to be alone. Teamwork is a dynamical interaction when two or more people depending on each other work for the same goal. They all have nearly the same values and everyone is aware of the aim and they need to reach the goal together in a determined period of time. Everybody has special roles and functions in the team and has a special part of the complex task, all of them are experts, and all of them have special tasks to do. These specialities must be harmonized, coordinated and structured so that the team could be effective. To become an effective team, members need to share the place, the information, the thoughts and feelings, they need to communicate and talk to each other [25].

Nowadays it is typical to work 10-12 hours a day, many workers are spending even longer hours working. Due to technology, work is not bound to the workplace anymore; employees can work also day and night at the workplace and at home too. It is suggested that the distinction between traditional (face-to-face, co-located) and virtual teams (dispersed, global) is no longer needed, as all types of teams in organizations today are characterized by degrees of virtuality, including physical distance, technology support, and time spent apart. In the so-called traditional teams all members are located in the same building, but in the so-called hybrid teams the major part of the team is located in the same building but some of the teams are distant, whilst in distributed teams all team members are in a different location.

The locational boundary refers to any physical dispersion of team members, such as different geographic locations or different workplaces at the same geographic location. The temporal boundary encompasses lifecycle and synchronicity. Lifecycle captures the extent to which a team is temporary or ongoing, while synchronicity refers to the timing of member interaction on the group's task. The relational boundary refers to the differences in relational networks of virtual team members, their affiliations with other teams, departments, organizations, and cultural sub-groups.

A virtual team or global team is a group of individuals working across time, space, and organizational boundaries using a common electronic collaboration technology or virtual space, sometimes they may never meet face to face [26].

The main characteristics of a virtual team are: members are highly committed to achieve the common goal; but they have interdependent performance goals for which they might have complementary skills; they share an approach to work for which they hold themselves mutually accountable. Similar team processes can be seen in the case of open source projects, when geographically distributed, internet based community of programmers bring their voluntary contribution to develop a widely and freely used software product. In certain organizations the software developers, having deep knowledge about different gaps, problems in software programs are able to formulate future needs in order to improve software [22]. All these members are involved in resolving these specific needs hereby they voluntarily afford energy and time, without any direct compensation and remuneration. Besides accomplishing their work tasks these (physically separated) employees voluntarily and spontaneously associate in order to obtain their own aims, in this manner they emerge from their every-day work environment in space and time, becoming a "bottom-up emergent virtual team" member. The participants of this alternative form of virtual teams - consisting of different employees within the same organization - demonstrate their joint viability through the improvement of the whole organization effectiveness. Advantages of emergent virtual teams are:

- Self-rewarding: the team members work with a strong intrinsic motivation, without any direct compensation, spending their spare time getting involved in different improvements.

- Job satisfaction: the output of their work leads to a high job satisfaction, having positive effects on other job related performance as well.

Disadvantages of bottom-up virtual teams: working with an extremely high commitment in emerging virtual teams can easily lead to narrow-minded attention, interactions, having negative effects on the "real working life".

\subsection{Practices for improving the virtual team}

In the virtual team due to the infrequent face-to-face communication, the team members must keep in line the communication by means of the intensive use of various communications tools. In addition, team members themselves need to be responsive, quickly returning telephone calls and responding to e-mails. It is definitely indispensable to support other team members, communicate effectively, and have a variety of specific skills. Effective communication includes transferring ideas, sharing information, listening to and internalizing the ideas of others, and notifying team members of any problems or issues. For this reason virtual teams need the following skills: ability to organize effectively, competency in an individual's area of responsibility, adequate technical skills as required to use information technology tools, and good management skills. 
4.2 Comparing virtual teams with traditional face-to-face teams

Members of traditional teams have access to numerous resources and supports on which they can easily rely, whilst a virtual team member has fewer mechanisms to gather information informally or to receive informal feedback and advice to realign goals and activities. A virtual or distributive team member is typically more dependent on information technology for communication and is more likely to be isolated from the rest of the team. Thus, this team member is less likely to know his/her colleagues' status and activities unless they are explicitly shared and rely more heavily on his/her own resources. Consequently, knowing who will be able to give a timely response in the team is more critical for a shared team member than for a traditional team member who has more options for interacting with organizational members. It is supposed that a virtual team member needs to be more reliant on himself/herself than a traditional team member does.

Co-located or so-called traditional team-members are very near to each other which makes communication and cooperation much easier. But dispersed team members need to work together. Proximity has several advantages [27]. People in the same space can observe each other, percept each others' reactions and answers. Collaboration is also much likely to happen when people are in the same place. Proximity enables communication easier to initiate and conduct it, as well as to maintain awareness of what the other team-members do [21].

It is necessary to get enough information in order to do our work effectively. It is very important to know in which phase the project is in order to decide how much information is needed. People are predicted to prefer richer media when they get uncertain or unroutine tasks, but in the case of more routine and predictable tasks less media can be enough and efficient. Teams can choose from a broad scale of technologies to supplement or replace face-to-face interaction. Technologies differ in their extent of media richness as communication channels and in the extent to which they enable synchronous collaboration between team members. Whereas videoconferencing is relatively high in media richness and in synchronicity, e-mail is lower in both dimensions. Other commonly used technologies to support team functioning are the telephone, web sites, instant messaging, fileand application-sharing, electronic bulletin boards, group decision support systems, and real-time calendar/scheduling systems. Face-to-face communication is said to be the richest media, because all of the communicational cues are available and feedback is also possible. Videoconferencing is also a rich form of communication because visual and auditory cues are also available but people are not in the same place [32]. The telephone is less efficient because of the lack of visual information. Written versions of communication are the less efficient because they only contain the information without any nonverbal expressions. This lack of social cues can lead to deindividuation, which is neither good for the organization nor for the individual. This deindividuation can result in uninhibited, antinormative behaviour such as reduced politeness, intolerance, more conflicts and hostile behaviour.

\subsection{Developing mutual knowledge}

The modern equipment basis can help the team to develop such mutual virtual knowledge that can be reached by every team member. This common ground is very important because the unit of time and space is broken up in the virtual world, members in different countries work in different frames and conditions of work. Sometimes they do not work at the same time but they need the same information and knowledge to be effective together. The shared mental model among team members allows them to develop a common information basis. Such an automated system is needed that can be accessed by anyone in the company, wherever they are. Without common understanding, without shared information, communication would be more difficult because the same information can be interpreted by the sender and by the receiver in a different way [20]. Mutual knowledge is required across a range of dimensions within teams. It means knowledge of the team's goals, the task, the history of the task, the current status of the processes, future directions, interactions, personality and characteristics of team members and the context of the work [1].

\subsection{Trust}

Trust is a very important element of teamwork. If people work together it is necessary to share information, thoughts and opinions among each other. If people work together it is important to have the same goals and to want to reach these goals together [12]. Ensuring this team members need to have trust to each other. Without trust people are less willing to share information openly which could hinder improvement and successful team function. Researches connected with trust found that teams with trust have better processes than teams without trust.

It is an important question if "trust needs touch" or not [12]. Is it necessary to have face-to-face contact for trust or not? Do team members have to meet personally for trust? Do team members have to meet regularly for trust? The time spent together and social knowledge is responsible for the trust. How can it work in virtual teams then? A prevailing assumption about trust in dispersed teams is that trust will be lower than in co-located teams but it is not known for sure. People who have been in the same team for a long time have stronger trust to each other. When team members get a lot of personal, social information about each other, they will feel stronger trust in the others [4]; [15]. Related to project teams - mainly to virtual project teams - it is important to deal with trust because controlling and supervising work can be managed much better by trust than by control (Handy, 1995 [12]). 


\section{Conclusion}

The nature of work is changing dynamically. Workers are expected to have special skills and they have to be very fast, flexible and to have excellent technological skills in order to be able to stay on the market. Organizations are also expected to give immediate reactions and to be proactive. Traditional approach and work style are not competitive enough anymore. That is why in addition to the traditional type of work a lot of atypical types of work are appearing. These atypical types can only function near typical type of work but in the present world they must function together. Among these atypical types of work, project work is the most prevalent, which is the only type of work ensuring rapid decisions, reducing inefficiencies in organizational processes, and following and responding to changes continually. Most important advantages of project work are:

- more point of views,

- multi-lateral coordination,

- cooperation in the team,

- structure that makes project teams independent from the organization,

- objectivity in performance appraisal,

- adaptability that makes project organization flexible.

Besides advantages there are disadvantages too:

- conflicts among team members,

- conflict among project team and the organization,

- uncertainty in responsibility and social loafing in the project team,

- conflicts related to double responsibility,

- decrease of effectiveness if there is not enough human resources to manage all the tasks,

- little power of project management and project team leaders in the organization,

- continuous lobbying needed to stay alive as a project team.

Besides face-to-face teams number of virtual teams is also increasing. Virtual team work is a special type of team work, when people participating in the same project, are geographically isolated from each other. It is a special type of work because to become an effective team it is usually necessary that the members share the place, the information, the thoughts and feelings, and they communicate and talk to each other personally. In virtual team work, the unity of place and time is broken, so information, thoughts and feelings can only be shared by means of modern technical equipment. Nowadays these types of work are mixing; all of them are typical on the labour market. They must be harmonized and they must function together to ensure effectiveness and successful cooperation. Attendance of (virtual) project teams can be connected to a new kind of work attitude. Tasks and responsibility are also special in project teams and self-managed teams are typical among such teams. The role of the leader is changing, leaders have to find balance between task and person orientation, and democratic leadership style can be practical. Both in face-to-face and in virtual teams it is very important for effective team work to share the knowledge and the information. At the beginning of common work it is difficult for team members to understand each other and they need a lot of verbal communication. Due to communication they generate a common platform for themselves: a shared mental model. This shared mental model contains a lot of information about them, about the tasks, the goals, the circumstances, the thoughts, attitudes and behaviour. This makes the team more effective, they will be able to cooperate better and they can achieve better performance by it.

\section{References}

1 Axtell C, Fleck S, Turner N, Virtual teams: Collaborating across distance, International Review of Industrial and Organizational Psychology, 19, (2004.), 205-249, DOI 10.1002/0470013311.ch7.

2 Avolio B, Bass B, Developing potential across a full range of leadership: Cases on transactional and transformational leadership, Lawrence Erlbaum Associates, 2002., ISBN 9780805838947.

3 Cannon-Bowers J, Salas E, Converse S, Shared mental models in expert team decision making, Individual and group decision making: Current issues (Castellan N (Jr.), ed.), Hillsdale, NJ, 1993., 221-246.

4 Crisp C, Jarvenpaa S, Trust over time in global virtual teams, Academy of Management Conference (Washington, DC, 2000.)

5 Cohen S, Gibson C, Putting the team back in virtual teams, 18th Annual Conference of the Society for Industrial/Organizational Psychology (Orlando, FL, 2003.)

6 Devine D, Philips J, Do smarter teams do better : A meta-analysis of cognitive ability and team performance, Small Group Research, 32, (2001.), 507532, DOI 10.1177/104649640103200501.

7 Dudás $\mathbf{F}$, Az emberi erôforrás-gazdálkodás, valamint a minöségfejlesztés szerepe a közigazgatás korszerúsítésében. (The role of human resource husbandry and quality developement in the modernization of civil service), Magyar Közigazgatás (3-4), (2006.), 136-144.

8 Esher S, Grabarkiewitz R, Frese M, van Steekelenburg G, Lauw M, Friedrich $\mathbf{C}$, The moderator effects of cognitive ability on relationship between planning strategies and business success of small scale business owners in South Africa: A longitudinal study, Developmental Enterpreneurship, 7(3), (2000.), 305-318.

9 Frese M, Work and organizational psychology, Psychology: An integrated approach (Eysenck M, ed.), Addison Wesley Longman, Essex, England, 1998., 624-667.

10 , The changing nature of work, Work and Organizational Psychology, Blackwell Published, Oxford, 2000.

11 Gajdusek G, Vezetôvé válás a magyar közigazgatásban. Egy kritikai megközelítés (Becoming Leader in the Hungarian Civil Service. A Critical Approach), Közigazgatási Szemle (3), (2007.), 26-35.

12 Handy C, Trust and the virtual organization, Harvard Business Review, 73(3), (2005.), 40-50.

13 Heerwagen J, Kelly K, Kampshroer K, The changing nature of organizations, work and workplace, 2006., available at http://www.wbdg.org/ resources/chngorgwork.php

14 Hofstede G, What did GLOBE really measure? Researchers' minds versus 
respondents' minds, Journal of International Business Studies, 37, (2006.), 882-896.

15 Jarvenpaa S, Leidner D, Communication and trust in global virtual teams, Organization Science, 10(6), (1999.), 791-815.

16 Juhász M, A munka természetének változása (The change of the nature of work), Munkaügyi Szemle, 53(1), (2009.), 24-31.

17 _ Effects of the shared mental model on the team performance, BME, APPI Ergonómia és Pszichológia Tanszék, Konferencia (2007.)

18 Juhász M, Répáczki R, Projekt-teamek terjedése a magyar szervezeti kultúrákban (Spreading of Project Teams in the Hungarian Organizational Cultures., „Közösen a jövő munkahelyeiért” Alapítvány Kuratóriuma ( “Collectively for Workplaces of the Future" Foundation), Budapest, 2010.

19 Klimoski R, Mohammed S, Team mental model: Construct or metaphor, Journal of Management, 20(2), (1994.), 403-437, DOI 10.1016/01492063(94)90021-3.

20 Krauss R, Fussell S, Mutual knowledge and communicative effectiveness, Intellectual teamwork: Social and technological foundations of cooperative work (Galegher J, Kraut R, Egido C, eds.), Lawrence Erlbaum Associates, Hillsdale, NJ, 1990., 111-146.

21 Kraut R, Fussell S, Brennan S, Siegel J, Understanding the effects of proximity on collaboration: Implications for technologies to support remote collaborative work, Distributed Work (Hinds P, Kiesler S, eds.), MIT Press, Cambridge, MA, 2002., 137-162.

22 Lea M, Spears R, de Groot D, Knowing me, knowing you: Anonymity effects on social identity processes within groups, Personality and Social Psychology, 27(5), (2001.), 526-537, DOI 10.1177/0146167201275002.

23 McGregor D, Human side of enterprise, McGraw Hill, New York, 1960, ISBN 978-0070450981.

24 Mathieu J, Goodwin G, Heffner T, Salas E, Cannon-Bowers J, The influence of shared mental models on team process and performance, Journal of Applied Psychology, 85(2), (2000.), 273-283.

25 Martins L, Gilson L, Maynard M, Virtual teams: What do we know and where do we go from here?, Journal of Management, 30(6), (2004.), 805835, DOI 10.1016/j.jm.2004.05.002.

26 O'Leary M, Cummings $\mathbf{J}$, The spacial, temporal and configurational characteristics of geographic dispersion in work teams, Management Information Systems Quarterly, 31(3), (2002.)

27 Olson G, Olson J, Distance matters, Human-Computer Interaction, 15(23), (2000.), 139-178, DOI 10.1207/S15327051HCI1523_4.

28 Rixer Á, Új közigazgatás - változó társadalom. (New Civil Service - Changing Society), Közigazgatási Szemle(2), (2007.), 14-32.

29 Schein E, Career anchors revisited: Implications for career development in the 21st century, The Academy of Management Executive, 10(4), (1996.), http://www.solonline.org/res/wp/10009.html

30 Solansky S, Leadership style and team processes in self-managed teams, Journal of Leadership and Organizational Studies, 14, (2008.), 331-341, DOI $10.1177 / 1548051808315549$.

31 Tichy N, Devanna M, The Transformational Leader. $2^{\text {nd }}$ Ed, John Wiley \& Sons, 1990., ISBN 978-0471822592.

32 Veinott E, Olson J, Olson G, Fu X, Video helps remote work: speakers who need to negotiate common ground benefit from seeing each other, $\mathrm{CHI}$ 99 Conference on Human Factors in Computing Systems (Pittsburgh, PA, 1999.) 